\title{
ESTUDOS DOS EFEITOS DO MANTO DE INTEMPERISMO SOBRE ANOMALIAS DE VLF GERADAS POR CORPOS INCLINADOS: MODELAGEM NUMÉRICA ATRAVÉS DE PROGRAMA eGs
}

\author{
Gilberto Emanoel Reis Vogado \\ Orientador: Dr. Om Prakash Verma (UFPA) \\ 116 p. - Dissertação (Mestrado) - Defesa 28.10.2005
}

\begin{abstract}
RESUMO. As referências apresentadas e utilizadas através de métodos indutivos de propagação eletromagnética E.M., são utilizadas na prospeç̧ão de minerais, entre outros, haja vista que em regiões tropicais existem camadas superficiais condutivas (manto intemperismo) que levam a influenciar, evidentemente, na interpretação do resultado real. Em nossa região Amazônica, o manto apresenta-se bastante desenvolvido e condutivo. 0 objetivo deste trabalho é estudar os efeitos dos mantos sobre anomalias VLF, devidos a corpos tabulares inclinados em contato ou não com o manto (manto galvânico e manto indutivo). Deste modo, foram realizadas umas séries de experimentos em modelagens numéricas através da eGs, considerando-se diferentes parâmetros de resposta para o manto e para o corpo. Os trabalhos de modelagem numérica, bem como seus resultados foram apresentados por diversas situações, como: variação da profundidade do topo do condutor, variação do mergulho do condutor, variação da condutância do manto, entre outros. Para interpretação dos resultados, foi gerado um conjunto de curvas considerando-se valores pico-a-pico das anomalias de Tilt Angle e de Elipsidade. Os resultados foram sintetizados em um outro conjunto de curvas reunidas em diagramas de Argand. Na medida em que se aumenta a profundidade, o pico-a-pico e a forma do pico da anomalia do Tilt Angle e da Elipsidade diminuem na presença do manto, ou na ausência do mesmo, fazendo com que este se afaste do ponto de "Cross-Over". Para um condutor da mesma espessura, o aumento da condutância causa um aumento nas anomalias de Tilt Angle e da Elipsidade. 0 efeito geral na variação do mergulho do condutor é o de causar uma assimetria nos perfis de Tilt Angle e Elipsidade. 0 aumento da condutância do manto de intemperismo causa uma diminuição nas anomalias de Tilt Angle e de Elipsidade. Há rotação de fase no sentido anti-horário,sendo mais intensa para grandes valores de condutância do corpo. Na presença do manto, o corpo parece estar a uma profundidade inferior à verdadeira e, tendendo, a ser menos condutivo.
\end{abstract}

ABSTRACT. In this dissertation I have studied the effect of partially conducting overburden on the VLF anomalies of an underlying inclined conducting half-plane. In tropical climate, overburden is normally well developed due to climatic conditions. This study is realized through numerical modeling using finite elements and algorithms computing the results employing the eGs developed by Luiz Rijo of the Department of Geophysics of the Federal University of Pará, Brazil. In these numerical experiments two geoelectrical situations between the overburden and the underlying half-plane are considered: one when they are in galvanic contact called as "galvanic overburden" and the other when they are not in contact called as "inductive overburden". The depth, dip and conductance of the half-plane is varied along with the conductance of the overburden in this study. The results are presented in the form of Tilt-Angle and Ellipticity profiles. The Ellipticity profiles are highly affected by the presence of both types of the conducting overburden. The minor positive and negative peaks in the central part of the profile disappear as the overburden conductance increases. Initially there is an enhancement in the ellipticity anomaly at the lower conductance of the overburden but then it decreases as the overburden conductance increases. However, the tilt-angle anomalies decrease monotonously. Also, in both the ellipticity and the till-angle profiles, the distance between the peaks become shorter due the overburden. Consequently, the target depth is interpreted as shallower than the real. The index of asymmetry, used to determine the dip of the half-plane, is also affected by the overburden. Therefore, the dip determination is hampered in the presence of the overburden. An anticlock wise rotation in Argand diagram due to increase in the overburden conductance, result in interpretation a target of less conductance than the real value. Therefore, the presence of the conducting overburden should be taken into the consideration during interpretation of the VLF anomalies. 